\title{
Reinforcement of Public Relations Position in Structure of the Secondary Education Institutions Organization in Semarang ---A Case Study in Semarang Senior High School
}

\author{
Agus Naryoso \\ Communication Department of Undip \\ Semarang, Indonesia \\ (agunaryoso@gmail.com)
}

\author{
Sri Budi Lestari \\ Communication Department of Undip \\ Semarang, Indonesia \\ (lestarisamadikun@gmail.com)
}

\begin{abstract}
High School is a place of education to produce qualified generations. A good school is able to create outstanding students. School achievement is generated through good institutional managements, one of which is public relations department. Every school that has a vice-principal in public relations affairs should be able to design public relations program that can improve school performance better. Ideally, the school put Public Relations as part of dominant coalition involved in school policy planning and strategic decision making. The school principal and public relations should not only carry out activities that are one way promotions such as creating of banners, billboards, leaflets, but also design programs that answer public expectations. Public Relations is required to communicate the important role and significant contributions of Public Relations to all sectors at school in achieving the objectives of secondary education.
\end{abstract}

Keywords-High School; Public Relations; Management Dominant Coalition

\section{INTRODUCTION}

Public Relations plays an important role in achieving objectives of private and public organizations. Ideally, Public Relations through the function and role of communication should be able to bridge the interests of the organization in reputation developing. In the context of public institutions, Public Relations plays an important role to communicate the policies and regulations of government programs. Unpopular government programs have impact or great influence on formation of public attitudes. Management of secondary education in Indonesia will grow better if it is supported by public relations activities.

Case of School Operational Aid (BOS), which is a central government policy and it is formulated into compulsory program of local government, in implementation found many obstacles. Most of the cases that come related to misappropriation of such aid which is not appropriate with the objectives set. The School Operational Aid is used to support cost of daily activities but in implementation it is used for consumptive costs such as traveling of teacher, overtime incentives and also teachers' uniform purchasing.
In this context, Public Relations does not indicate its role at all, large and wide negative publicity does not get Public Relations positive response, so that during its development the news is not declining but more massive, sometimes the content is not proportional (cover both side). Secondary education managers are not accomodated for clarification of the negative publicity that appeared, written by the mass media.

Violence cases in education also become negative news that improve bad reputation of secondary education in Indonesia. Through writing, media accused the secondary school teachers who conduct violence make secondary education in Indonesia more collapse. Start from physical violence to sexual violence such as teachers ravishing the students, teachers doing sexual harassment, teachers doing intensive rude communication repeatedly.

The lack of space for clarification from the school managements more due to the opportunities presented by the mass media are not used properly. Secondary school managers more hold themselves aloof from mass media such as they difficult to contact, give stingy comment, avoid on contact with the media, even they tend to build stigma of mass media as the money seeker journalists and muckracking journalism practice or the presence of the media is to seek negative side for report materials.

The practice of Public Relations at high school institutional formally in Semarang is quite good, it can be proved that almost all schools have the Deputy Principal Officer who handles the activity of Public Relations (Public Relations). Ideally, the existence of optimized PR officials are able to anticipate the emergence of a potential crisis, but in practice not many of them are able to translate and execute the Public Relations activities. There are a lot of deputy principal officers who do not have a good understanding of Public Relations activities.

School Public Relations Managers are not sensitive to identify the issues, and even they tend to be apathetic, pay no attention and ignore the issues. This is compounded by the pride among managers of public schools, there is a negative or positive news, it does not affect anything, they still get a lot of registrants. The Principal understand and interpret the Public 
Relations activities only on Communication Technicians such as creating of banners, leaflets, calendars, religious commemoration, art and culture show as annual activities agenda. The most strategic Public Relations program is the program that has characteristic such as two-way communication program. The program which is implemented largely provide opportunities to the two-way communication activities of the organization and the targeted public, this activity is based on solid empirical data which is the result of insight and mapping the public needs. Frances L. O'Reilly and John J. Matt (2013) stated that the Public Relations need to use the guide of research result for designing programs that suit the location of the school on their territory.

In practice, schools have only a few programs which opens intraction opportunities with the public. Public Relations of school should be able to play an active role to support other units such as curriculum, finance and improvement of teachers competence and students achievements. Rhee (2004: 18) asserted that public relations should be able to intepret its functions more integrated, be representative of all units within the organization in relation with interaction of school's public.

The organizational structure of senior high schools accommodate the position of vice principal in public relations affairs, when it refers to the structure of the organization in detail, there is no staff as may be authorized under the vice principal in handling public relations work. The human resource constraints make public relations activities only to continue the activities that have already existed in previous year that have minimum creativity and innovation. Academic achievement is also rarely used as a media relations strategy to eliminate the appearance of negative publicity.

\section{DISCUSSION}

McCroskey and Steven (1999), Dean Kazoleas \& Jason J. Teen emphasized that the credibility of the organizations affected by many factors such as competence, goodwill, initiative to open channels of communication and public relations. The position of public relations in the organizational structure at high school in Semarang showed that Public Relations yet enjoys a strategic position in the organization. This fact is reinforced by the position of vice principal in public relations affairs but he is not supported by qualified staffs to help the implementation of school public relations policy.

Research conducted on the scientific background, the majority of objects do not have relevant background such as communications, journalism or business administration, but most come from Pedagogy and Education Management Affairs. The reality affect on the lack of innovation and creativity when designing and implementing public relations activities. Most just do technical activities such as promotion of new students registration, making calendars, religious commemoration. The vice Principal does not conduct the role of public relations optimally as "expert prescriber". He does not implement a lot of function of boundary spanning, doing identification and mapping the issues, providing advice on school leaders to carry out communication activities to respond issues, and to develop public relations programs to answer public expectations.
Public Relations of school, continues more the previous programs of one way communication activities than two-ways communication. One way communication can be seen in creating of banners, briefing during flag ceremony and providing information by the class teacher in giving school report cards. Laura (2001:7) The role of Public Relations of secondary schools should be reinforced not only in the role of public information but also in strategic functions such as school promoting, reputation managing, publications, newsletters productions, website management, media relations, issues management, campaigns, communication crisis, public relations research polling and surveys, student achievement encouraging.

Public Relations of school in excellent perspective of public relations theory emphasizes the strategic management function with greater autonomy for the public relations department that is separate from the marketing function. Vice principal in public relations affairs as public relations official representatif should continue communication and coordination intensively with the principal as the highest officials. Public Relations of school should be able to prioritize the principle of two-way communication between the school and all of the relevant public.

Grunig (2001:9) emphasized, ideally, public relations should be part of the management dominant coalition that plays strategic role from the planning step to the organization's strategic decision making. Communication recommended to more emphasize on two-way communication for balancing interests of the organization with the public. The position of Public Relations is more optimal if it is able to anticipate the public interest creatively such as curriculum policy, students and school achievements and communication programs developing that answer the public expectations.

The position of Public Relations is not just as complement of school leadership but also proactively mapping the public interests and balancing it with the organization interests. This activity is a very strategic position, considering stigma of public relations position of secondary school in Semarang that only as officer who promote the school and attract new students to study at the school. Through its strategic position, Public Relations can provide insight and knowledge for policy makers in the School of Public Relations need to help reaching school achievement.

\section{CONCLUSION}

The implementation of Public Relations activity in High School in the city of Semarang has not been maximum implemented. This reality is seen from the strategic role of public relations that has not been optimal to develop strategic relationships with stakeholders through mutually beneficial two-way communication. Public Relations in high school only implement promotion role in registration of new students through banners, leaflets and billboards. The existence of vice principal in public relations affairs only act as a complement to the organizational structure, he has not become part of the management dominant coalition that involved in strategic planning and policy step making. 


\section{REFERENCES}

[1] James E. Grunig, "Public Relations And Strategic Management: Institutionalizing Organization - Public Relationship In Contemporary Society," Central European Journal Of Communication 1, USA, pp. 1-22, 2011.

[2] James E. Grunig, "Public Relations And Strategic Management: Institutionalizing Organization - Public Relationship In Contemporary Society," Central European Journal Of Communication 1, USA, pp. 1-22, 2011.

[3] Larissa A. Grunig. and James E. Grunig and David M. Dozier, "Excellent Public Relations And Effective Organizations," Lawrence Erlbaum Associates Publsisher, New Jersey, pp. 1-668, 2002

[4] Frances L. O' Reilly amd John J. Matt, "Public Relations Opportunities For School Utilizing Innovations In Virtual Communities," Journal Of Education And Learning, Montana, pp. 1-5, 2013.
[5] Rhee Y, "The Employee Public Organization Chain In Relationship Management: A Case Study Of A Government Organization," Unpublished Doctoral Dissertation, University Of Maryland, College Park, pp. 1-30, 2004

[6] Laura Carlsmith and Jennifer Railsback, "The Power Of Public Relations In Schools," Northwest Regional Educational Laboratory, pp. $1-35,2001$.

[7] Dean Kazoleas, Ph.D., APR and Jason J. Teven, Ed.D, "Public Relations And Organizational Credibility: Refining The Definition, Measurement And Assessment Of Organizational Trust," A Publication Of The Pasific And Assian Communication Association. Fullerton, pp. $1-14,2007$ 